\title{
Movimento pendular e ocupação na Região Metropolitana de Recife - PE
}

Mobilité pendulaire et occupation dans la Région Métropolitaine de Recife - PE

Commuting and occupation in Metropolitan Region of Recife

Movimiento pendular y ocupación en la Región Metropolitana de Recife

\section{Clarice Antoun Martinho, Mauricio Gonçalves e Silva e Cesar Ajara}

\section{(2) OpenEdition}

Journals

\section{Edição electrónica}

URL: http://journals.openedition.org/espacoeconomia/2461

DOI: 10.4000/espacoeconomia.2461

ISSN: 2317-7837

\section{Editora}

Núcleo de Pesquisa Espaço \& Economia

\section{Refêrencia eletrónica}

Clarice Antoun Martinho, Mauricio Gonçalves e Silva e Cesar Ajara, « Movimento pendular e ocupação na Região Metropolitana de Recife - PE », Espaço e Economia [Online], 9 | 2016, posto online no dia 19 janeiro 2017, consultado o 10 dezembro 2020. URL : http://journals.openedition.org/ espacoeconomia/2461; DOI : https://doi.org/10.4000/espacoeconomia.2461

Este documento foi criado de forma automática no dia 10 dezembro 2020.

\section{cc) (†)}

Espaço e Economia - Revista brasileira de geografia econômica est mise à disposition selon les termes de la licence Creative Commons Attribution - Pas d'Utilisation Commerciale - Partage dans les Mêmes Conditions 4.0 International. 


\title{
Movimento pendular e ocupação na Região Metropolitana de Recife - PE
}

\author{
Mobilité pendulaire et occupation dans la Région Métropolitaine de Recife - PE \\ Commuting and occupation in Metropolitan Region of Recife \\ Movimiento pendular y ocupación en la Región Metropolitana de Recife \\ Clarice Antoun Martinho, Mauricio Gonçalves e Silva e Cesar Ajara
}

\section{Introdução}

O objetivo deste artigo é analisar o perfil ocupacional da população que realiza movimento pendular na Região Metropolitana de Recife, utilizando os resultados do Censo Demográfico de 2010. Identificou-se como necessária a construção de uma metodologia de organização dos dados. Os dados do Censo foram agrupados segundo categorias ocupacionais definidas no âmbito da pesquisa, a partir de dois critérios: nível de especialização e atividades socioeconômicas.

A base teórica tomou como pilares a relação entre a formação do espaço metropolitano e o movimento pendular; e o perfil ocupacional no contexto das metrópoles. As unidades espaciais de análise adotadas foram os municípios da Região Metropolitana (RM) de Recife e o total da RM.

Por último, enfatiza-se que a análise de resultados privilegiou os fluxos de deslocamentos populacionais mais evidentes, tanto no que se refere aos municípios que recebem ocupados, quantos das ocupações que motivam tais deslocamentos.

\section{A Formação do Espaço Metropolitano e a Pendularidade}

No Brasil o fenômeno metropolitano data da segunda metade do século XX, em meio a um grande processo de transformação econômica, social e espacial, quando a industrialização se tornou carro chefe na economia nacional. A urbanização reflete a 
face espacial deste processo, resultado, em grande parte, dos grandes movimentos migratórios rurais - urbanos e do nordeste para o sudeste.

Em 1973 o governo institucionalizou nove Regiões Metropolitanas (São Paulo, Rio de Janeiro, Belo Horizonte, Porto Alegre, Curitiba, Recife, Salvador, Fortaleza e Belém) e criando organismos específicos que dessem conta da problemática metropolitana ${ }^{1}$.

Em 1988 a Constituição Federal incumbiu aos estados a definição das regiões metropolitanas, porém, sem estabelecer de critérios mínimos ou comuns o que veio a resultar em um quadro de realidades muito diversas, em termos de densidade populacional, taxa de crescimento econômico, provimento de serviços, etc' ${ }^{2}$. Em geral, trata-se de áreas onde diversas cidades interagem com frequência e intensidade, a partir de uma interdependência funcional baseada na unidade das infraestruturas urbanas e nas possibilidades que esse fato acarreta para uma divisão do trabalho interna bem mais acentuada ${ }^{3}$.

A Região Metropolitana (RM) costuma ter uma mancha urbana contínua sobre mais de um município, além de possuir elevados fluxos intermunicipais de pessoas, complementariedade funcional e integração socioeconômica. A RM destaca-se pelo próprio núcleo, ou seja, a metrópole e suas características. A esse respeito:

Considera a metrópole a cidade principal de uma aglomeração, destacando-se pelo tamanho populacional e econômico, desempenhando funções complexas e diversificadas, e relações econômicas com várias outras aglomerações, funcionando como centro de comando e coordenação de uma rede urbana ${ }^{4}$.

Castells afirma que a Região Metropolitana é uma forma espacial produzida por um "processo acelerado de urbanização global", em que a metrópole e sua região metropolitana são originárias dos seguintes processos: da ampla descentralização das grandes cidades para áreas adjacentes, e, da interconexão das pequenas cidades préexistentes cujos territórios se tornam integrados por meio de novas capacidades de comunicação $0^{5}$.

Nos grandes centros urbanos atuam economias de aglomeração, ou seja, há concentração espacial de atividades econômicas, estabelecimentos comerciais e serviços. Storper e Venables (2005) sistematizam as principais vantagens auferidas pela aglomeração econômica: diminui os custos de transportes e os custos de comércio, promove um melhor aproveitamento dos fatores produtivos (matérias primas, insumos, crédito, trabalho), produz retornos crescentes de escala, promove aproximação entre fornecedores, firmas e mercado consumidor e facilita a comunicação. Eles destacam o intercâmbio imaterial, especialmente a transmissão e a troca de informação e conhecimento, produtor de inovações, beneficiados pela proximidade física.

Em um determinado momento passam a atuar as "deseconomias de aglomeração": a aglomeração leva ao encarecimento do solo produzindo um perímetro urbano muito valorizado de forma que se buscam outros espaços distantes do centro, onde haja terrenos vazios e/ou baratos. Adicionalmente são apontadas como causas de deseconomias o preço da mão de obra, os incentivos fiscais, a qualidade de vida (poluição, violência, etc), conforme aponta Souza (2005).

Milton Santos destaca a Urbanização Corporativa em que há uma "produção do espaço necessário aos grandes capitais". Nesta, "o território é a base comum de operação para todos os atores, mas, sobretudo favorável às grandes corporações". Cria-se um sistema produtivo voltado para determinada atividade liderada por poucas e grandes empresas. São feitos lobbies, marketing, discursos, mobiliza-se o aparelho para direcionar os 
investimentos, pela prevalência de interesses e reivindicações setoriais. Sua atuação seleciona territórios 'privilegiados': assim, o espaço é conformado segundo os pontos de apoio das corporações no seu processo produtivo, ligando lugares estratégicos da produção, comercialização, informação, controle e regulação ${ }^{6}$.

Portanto, este é o processo de produção do espaço, nos moldes das grandes corporações, arregimentado pelo Estado, como resultado de uma estratégia de valorização de territórios privilegiados no espaço urbano, que afirmam a centralidade do seu núcleo valorizado ao expandir simultaneamente os limites da metrópole, uma vez que a população ocupa a periferia urbana metropolitana em busca de moradia.

o padrão metropolitano nuclear estrutura as metrópoles brasileiras, conformadas por um centro aglomerado e dotado das funções de centralidade de serviços, emprego e infraestrutura, com alta densidade populacional, enquanto os municípios vizinhos formam uma periferia, preferencialmente local de moradia, geralmente carente de serviços de infraestrutura e com baixa oferta de trabalho.

Esse modelo é ainda mais evidente nas regiões norte e nordeste do País. Afirma o Observatório das Metrópoles, para Recife:

A expansão populacional dos municípios metropolitanos do Recife reafirma a tendência centro-periferia que caracteriza as metrópoles brasileiras. Em um processo de periferização característico da expansão das grandes cidades brasileiras, a população pobre, também, se desloca na busca de condições de acesso a terra e à moradia: avança para as bordas da malha urbana e densifica o núcleo metropolitano, ocupando os terrenos que se situam às margens do mercado imobiliário ${ }^{7}$.

Os deslocamentos pendulares nos grandes centros metropolitanos refletem 0 distanciamento entre o local de moradia e o local de trabalho, estando, portanto, condicionados pelo processo de produção e ocupação do espaço. Sublinha-se a importância da lógica do acesso a terra e da localização das atividades econômicas, muitas vezes revelando aspectos produtores de segregação espacial da população8.

Jardim (2011) ressalta a existência de outros indicadores para compreender o fenômeno da pendularidade: são relevantes as condições do deslocamento - distância, duração, frequência, as condições de infraestrutura urbana de transportes e as políticas públicas habitacionais.

O mesmo autor chama atenção para a reestruturação produtiva, em curso desde a década de 1970, em que se adota progressivamente a produção flexível, colocando a informatização no centro do processo produtivo, esta sendo responsável por novas formas de trabalho e com efeitos sobre a mobilidade espacial da população. Ele cita como exemplo a produção de bens não materiais, como o infotrabalho ${ }^{9}$.

\section{0 trabalho no contexto metropolitano}

A noção de metrópole, do século XIX até meados do século seguinte, estava associada ao crescimento elevado das aglomerações urbanas fruto da revolução industrial. 0 século XX foi palco da consolidação da indústria fordista e da transição deste modelo para a produção flexível, parte da revolução técnico-científica informacional levando a terciarização crescente na economia.

Segundo Piquet (1997), há basicamente dois tipos de processos que caracterizam a terciarização. $O$ primeiro está relacionado às mudanças nas atividades industriais, que 
prestam serviços nas etapas anteriores e posteriores da produção propriamente dita. Estes passam a ser realizados por empresas externas, cujo objetivo é dar maior eficiência à produção, envolvendo assim uma tecnoestrutura e englobando profissionais e técnicos de alto nível.

o segundo processo corresponde ao contexto em que o terciário é um refúgio, que absorve os excedentes de mão de obra, através das atividades pouco capitalizadas e de baixa produtividade. As ocupações possuem baixas exigências de qualificação e baixa remuneração, tem caráter precário ou autônomo, sem as garantias e os direitos habituais e geralmente estão nos segmentos de comércio varejista, serviços pessoais e administração pública.

A possibilidade de fragmentação das etapas do processo de produção, onde as firmas descentralizam etapas da cadeia produtiva, leva a uma nova divisão espacial do trabalho. Assim, as empresas voltadas a produção de um mesmo produto ou serviço podem estar localizadas em cidades, ou até, países diferentes. Por possuírem importantes vantagens locacionais, as metrópoles atraem as atividades dos serviços avançados, mas também abrigam os serviços do terciário precário ou informal. Assim,

Vê-se que o processo de transformação que as grandes cidades e as metrópoles vêm experimentando é altamente complexo. Esses espaços ainda reúnem as maiores vantagens competitivas: centros de pesquisa e de formação superior, amplos mercados de consumo e de trabalho, boa comunicação com redes internacionais, presença das sedes sociais das grandes empresas. Em consequência, dentro das áreas metropolitanas coexistem tendências contrastantes e espaços que evidenciam trajetórias opostas: a espaços fabris degradados contrapõem-se novas paisagens industriais de fisionomia bastante distinta da tradicional ${ }^{10}$.

Os autores da abordagem pós industrial consideram a globalização como elemento chave na compreensão dos processos espaciais contemporâneos, formulando como categoria fundamental as "cidades globais" dentro de uma rede de cidades global. Para eles é tendência nas metrópoles, cidades globais, a polarização das ocupações nos dois extremos da estrutura ocupacional: Castells (2011) chama de formação de uma estrutura ocupacional dual, dividida em trabalhadores "talentos" e "genéricos"; Sassen (1993) atribui o formato de ampulheta, pela predominância tanto dos estratos de trabalhadores mais qualificados quanto os menos qualificados ou informais.

Enquanto os primeiros tem adquirido mais autonomia de decisão e poder de barganha, ganham altos salários e benefícios, os segundos continuam a proliferar, pois muitas de suas tarefas são servis, e não automatizáveis, além do que, "muitos trabalhadores, especialmente jovens, mulheres e imigrantes, estão dispostos a qualquer condição para a obtenção de um emprego" ${ }^{11}$. As empresas adotam a prática de terceirização dos serviços de baixo nível, como limpeza e manutenção, passando a contratá-los como fornecedores especializados.

A estrutura polarizada do mercado de trabalho decorre da nova dinâmica econômica em que serviços avançados especializados nas cidades globais são fundamentais para gerenciar e controlar redes globais de fábricas, postos de serviços, e filiais de escritórios, configurando uma nova lógica para a aglomeração econômica. A aglomeração envolve a atração da mão de obra qualificada para atuar nos segmentos modernos e exige a reboque o suprimento dos trabalhadores de baixa qualificação e renda. São as categorias que recebem baixos salários para atender os novos trabalhadores com altos salários, seja no âmbito dos segmentos modernos, seja nas suas próprias casas, ou no comércio de luxo ${ }^{12}$. 


\section{Região Metropolitana de Recife no contexto urbano atual}

Um estudo sobre a rede urbana brasileira ${ }^{13}$ revela, para a aglomeração urbana de Recife, uma tendência crescente à adoção de atividades de serviço modernas. Dá-se destaque aos serviços médicos hospitalares, à informática, ao turismo, importantes sedes da administração pública e a produção de conhecimento.

Recife vem se tornando referência em algumas especialidades médicas e hospitalares ortopedia, oftalmologia, cardiologia - além de investir em tecnologia médica, na área de diagnósticos feitos à base de equipamentos de alta tecnologia e comportar centros médicos como o Laboratório Farmacêutico de Pernambuco e a Fundação Hemocentro de Pernambuco.

O município sedia a administração pública estadual e órgãos como a Companhia Hidrelétrica do São Francisco, a Superintendência do Desenvolvimento do Nordeste, o escritório regional do Banco Nacional de Desenvolvimento Econômico e Social e a agência regional do Itamaraty. Há a Universidade Federal de Pernambuco, a Universidade Federal Rural de Pernambuco, Instituto Federal de Educação, Ciência e Tecnologia de Pernambuco-, universidades estaduais, privadas e centros de pesquisa.

No ano de 2000 foi criado o Projeto Porto Digital, localizado no bairro do Recife, sendo voltado para a produção de softwares, serviços de tecnologia da informação e comunicação, economia criativa nos segmentos de games, multimídia, animação, música, design e fotografia, tornando-se referência para o Brasil ${ }^{14}$.

Por outro lado, indica-se uma expansão do setor informal no espaço metropolitano. São atividades pouco intensivas em capital e tecnologia, com baixa produtividade, que auferem baixos rendimentos. Estas estão concentradas na produção industrial de vestuários, calçados, artefatos de couro e alimentos, nas ocupações de natureza administrativa e, principalmente, no subsetor do comércio de mercadorias, sobretudo, o comércio ambulante. Tais segmentos oferecem subocupações, sendo retrato do mercado de trabalho no Nordeste ${ }^{15}$.

Com relação ao turismo, o município de Olinda é considerado Patrimônio Cultural da Humanidade pela UNESCO. Há outros sítios históricos na RM como Igarassu e Itamaracá. Também constituem atrações turísticas, elementos da paisagem natural como a praia, os arrecifes, estuários, ilhas e reservas ambientais.

\section{Metodologia para Organização dos Dados}

De modo a realizar a análise do perfil ocupacional da população que se desloca na Região Metropolitana de Recife, considerou-se necessário estabelecer uma metodologia de trabalho para coleta e reorganização dos dados. A fonte utilizada foram os dados amostrais do Censo Demográfico 2010, cuja coleta foi realizada no Banco Multidimensional de Estatísticas do IBGE (BME).

O Censo adota a Classificação de Ocupações para Pesquisas Domiciliares (COD), baseada na Classificação Brasileira de Ocupações (CBO) do Ministério do Trabalho e na Clasificación Internacional Uniforme de Ocupaciones (CIUO-08), da Organização Internacional do Trabalho. 
O conceito de ocupação é construído a partir das atividades exercidas pelos cidadãos em algum tipo de relação de trabalho, seja emprego ou autônoma. A CBO e a CIUO-08 tem critérios muito parecidos de forma a permitir a comparabilidade, porém a primeira é adaptada à realidade brasileira, enquanto a segunda é internacional, mais abrangente. Ambas são baseadas nas competências mobilizadas para uma determinada atividade de trabalho, considerando a complexidade, a amplitude e a responsabilidade das atividades desenvolvidas no trabalho; as características do trabalho, como função, atividade econômica, processo produtivo, equipamentos e bens que levam a identificação do tipo de ocupação (MTE/CBO, 2014). São quatro níveis de agregação das ocupações. A COD mantém-se idêntica a CIUO-08 no nível mais agregado (grande grupo) e reagrupa alguns subgrupos principais, subgrupos e grupos de base, considerando as especificidades nacionais e as dificuldades de sua captação com precisão nas pesquisas domiciliares ${ }^{16}$.

A coleta dos dados para esse estudo no Censo 2010 tomou como referência o terceiro nível, Subgrupo, composto por 127 categorias, já que o nível mais desagregado Familia ocupacional contem 434 categorias, sendo muito grande e de difícil manuseio dos dados, enquanto o nível imediatamente acima Subgrupos principais reúne somente 43 categorias, insuficiente para a abertura no nível desejado.

Foi preciso produzir uma nova classificação de forma a agrupar as categorias ocupacionais de acordo com critérios estabelecidos no âmbito da pesquisa e na construção do objeto de análise. Adotaram-se como norte os seguintes elementos:

i) Nível de especialização e diferenciação das ocupações, podendo ser classificadas como ocupações em posições de comando (dirigentes, gerentes), em posições que requerem nível de formação superior, nível de formação médio e nível de formação básico. Quanto maior a posição, mais qualificada a função, e, ou, requerem-se competências mais específicas para exercê-la;

ii) Segmentos de atividades das ocupações: Militar, Administração Pública do Executivo, Legislativo e Judiciário, Saúde, Ensino, Ciências e Intelectualidade, Financeiro e Administrativo, Indústria, Serviços, Comércio, Agropecuário, Outros. Tais atividades, de segmentos socioeconômicos fundamentais, realçam atributos locacionais e históricos, uma vez que são reflexo da escolha dos tomadores de decisão (privados e públicos), contribuindo para o entendimento da distribuição geográfica de equipamentos e pessoas.

Dessa forma, cada item do banco de dados do BME das "Ocupações, Grupo 3", foi classificado conforme esses dois elementos descritos, produzindo uma nova categorização. São vinte e três os novos agrupamentos ocupacionais - Quadro 1 anexo.

A investigação ocorre no sentido de tentar responder as seguintes questões: Que ocupações exerce a população que se desloca para trabalhar? Quais municípios de origem dos ocupados (residência) e quais o municípios de destino (trabalho/ocupação) dos fluxos pendulares? O recorte espacial adotado foi o municipal, e a escala metropolitana tem sua lente posta sobre a relação entre os municípios da RM de Recife.

o desafio, assim, é dialogar o componente territorial incrustrado na pendularidade com as demais influencias, principalmente aquelas que atingem o mercado de trabalho, posto que a unidade de análise é a ocupação exercida pelo indivíduo que se desloca.

Definir os critérios para classificar as ocupações seguiu a necessidade de compreenderse pelo viés da especialização das funções em que medida circulam os trabalhadores, tal 
qual na terminologia empregada por Castells (2011), "genéricos" e "talentos". Sendo os primeiros àqueles trabalhadores com baixa qualificação, baixos rendimentos, ocupados sem qualificação específica. O segundo grupo é composto por trabalhadores com alta qualificação técnica, gerentes e executivos especializados e altos rendimentos, que atuam nos serviços avançados e a setores de ponta.

A análise empírica revela, entretando, que a estrutura ocupacional é complexa e ressalta os segmentos de trabalhadores ocupados de nível médio.

\section{Análise de Resultados}

A análise dos resultados foi baseada nos indicadores volume de ocupados, no saldo do movimento de ocupados e nos pares de origem-destino dos fluxos de população ocupada ${ }^{17}$.

O volume de ocupados corresponde ao total de ocupados no município $\mathrm{x}$, subtraindo-se os residentes que trabalham em outro município, e somando-se os ocupados que residem em outro município e trabalham no município x. Este indicador mostra como as ocupações se distribuem nos municípios da RM Recife considerando o total de ocupados e o deslocamento intermunicipal.

O Saldo do movimento foca no fluxo dos ocupados, já que corresponde à entrada de ocupados menos a saída de ocupados por município, revelando os municípios que absorvem o fluxo. Representa-se o deslocamento dos ocupados através de mapas, contendo os pares de municípios de origem-destino dos fluxos.

\section{Quadro Geral}

O conjunto dos municípios da RM detêm $35,5 \%$ ocupados nos serviços. No município de Recife esse resultado é ainda maior, 37,0\%, sejam residentes ou não. Para os segmentos Comércio e Indústria o quadro é distinto: a participação nos outros municípios da RM é maior do que em Recife. Há que considerar que a capital possui uma estrutura ocupacional mais diversificada, o que se reflete no gráfico 1 abaixo: 
Gráfico 1: Participação dos Segmentos Ocupacionais no Volume de Ocupados em Recife e demais municípios da Região Metropolitana -2010

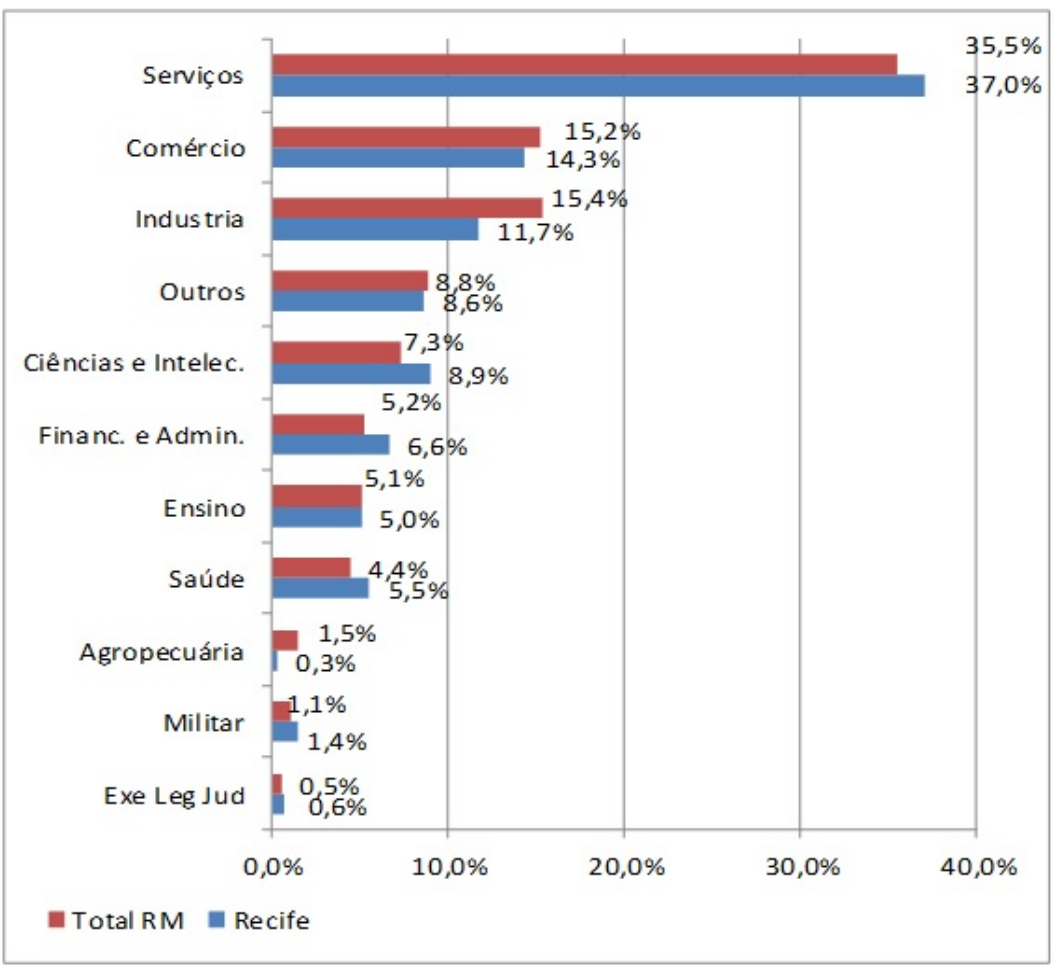

Fonte: elaboração própria, a partir de IBGE/Censo 2010.

De acordo com o nível de especialização, existem diferenças no comportamento de Recife e dos demais municípios, em especial nos Serviços. Enquanto nos segmentos comando e médio, Recife puxa o resultado da RM para cima, no básico é o contrário, os demais municípios têm uma participação mais elevada, conforme o gráfico 2.

Por outro lado, para a Indústria, Recife apresenta participação de 11,7\%, enquanto no conjunto os municípios apresentam 15,4\% (graf.1). Por nível de especialização, o segmento Básico indústria tem uma participação menor em Recife, sendo $7,5 \%$ vis a vis 10,3\% na RM. No Médio Indústria a participação dos municípios oscila, sendo Recife o segundo percentual mais baixo, 3,7\%. Os maiores percentuais são de Ipojuca, 10,6\%, e Cabo de Santo Agostinho, 7,5\%, vide o gráfico 3. 
Gráfico 2: Participação dos Serviços nas Ocupações em Recife e demais municípios da Região Metropolitana 2010

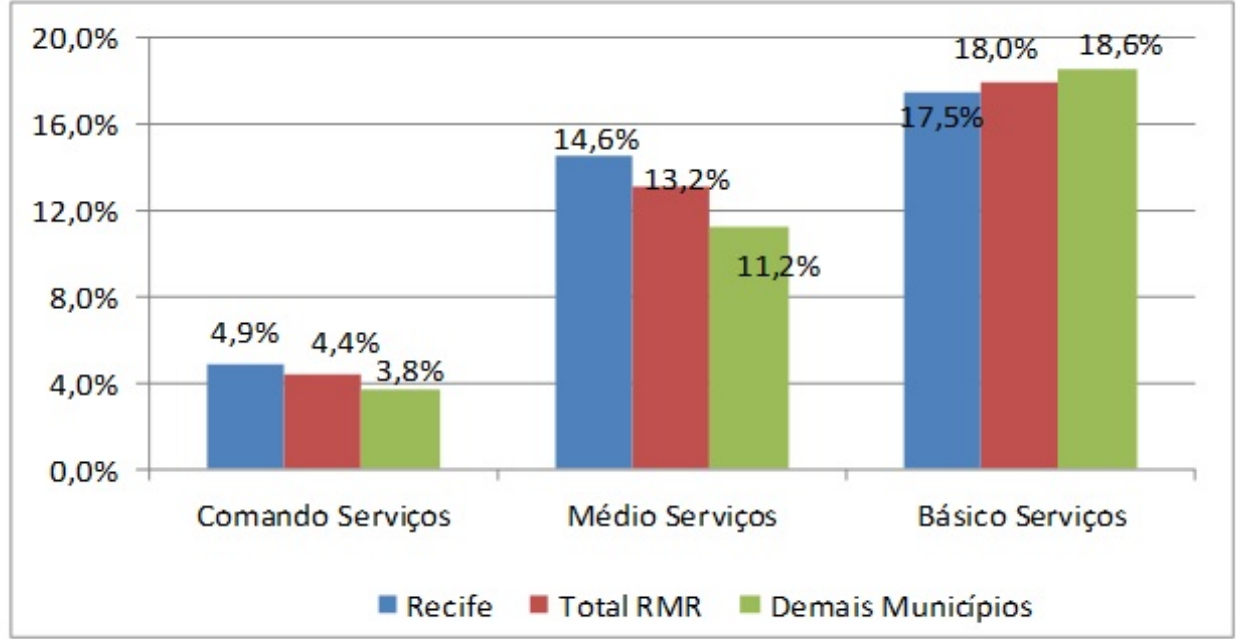

Fonte: Elaboração própria, a partir do Censo 2010, IBGE*.

Gráfico 3: Participação da Indústria nas Ocupações em Recife e demais municípios da Região Metropolitana 2010

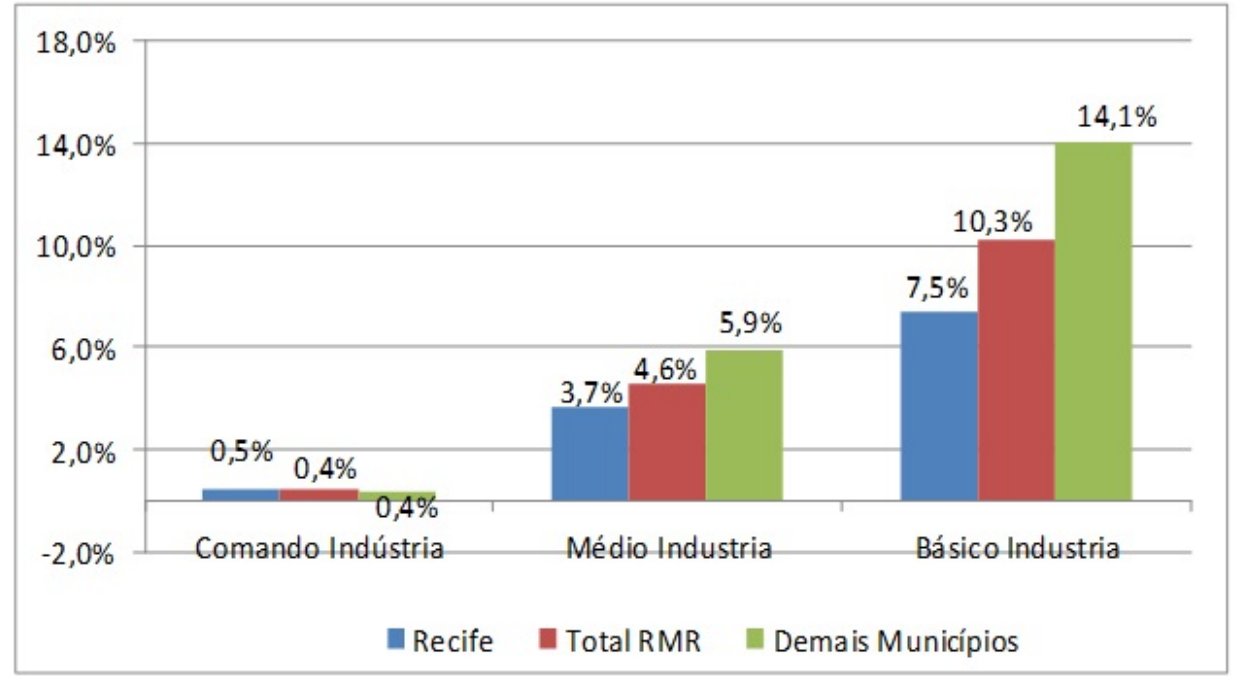

Fonte: Elaboração própria, a partir do Censo 2010, IBGE*

Obs*: Volume total do município (para cada município) $=100 \%$.

Em Recife também se destacam os segmentos Ciências e Intelectualidade e Financeiro $e$ Administrativo, com participação de $8,9 \%$ e 6,6\%. Esses segmentos tem peso maior na capital do que no restante dos municípios, sendo o quarto e o sexto segmentos com participação relevante e acima da mediana. No conjunto da RM esta participação é respectivamente, 7,3\% e 5,2\% (gráfico 1).

As Ciências e Intelectualidades abarcam ramos relacionados à produção e difusão do conhecimento (excluindo profissionais de Ensino) e alguns profissionais liberais. 0 segmento Financeiro e Administrativo também tem maior peso em Recife, comparado aos outros municípios, observando-se que, em Recife há 208 agências de instituições 
financeiras, número muito superior a qualquer outro município do estado de Pernambuco. Jaboatão dos Guararapes o segundo em número possui 22 agências, Caruaru 19 e Olinda $16^{18}$.

Os estratos superiores e comando exercem funções de destaque na estrutura ocupacional. Tratando-se de técnicos em cargos mais especializados e de gestão, exigem um nível de qualificação mais elevado e um aparato econômico e urbano para ser exercido. Dessa forma podem revelar a realidade socioeconômica e centralidades urbanas. Um dado ilustrativo da sua importância é o total de rendimento que estes ocupados geram na RM, como será visto na seção 4.2.

O volume de ocupação do Comando Serviços (ocupações ligadas à direção e à gerência de serviços especializados de administração, distribuição, logística, comercialização, vendas, tecnologia e turismo) tem um peso maior em Recife, $4,9 \%$, vis a vis $3,8 \%$ dos demais municípios da região metropolitana somados. O Superior das Ciências e Intelectualidades (ocupações relacionadas à produção do conhecimento e profissionais especializados) também apresenta o mesmo comportamento, tendo um peso de 5,1\% nas ocupações de Recife e somente 2,2\% no volume ocupacional dos outros municípios somados.

Para ocupações do nível comando ou superior, Recife lidera em todas as categorias, com participações acima dos demais municípios, como ilustra o gráfico 4 :

Gráfico 4: Participação das Ocupações Superiores e Comando em Recife, demais municípios da RM e total de municípios - 2010

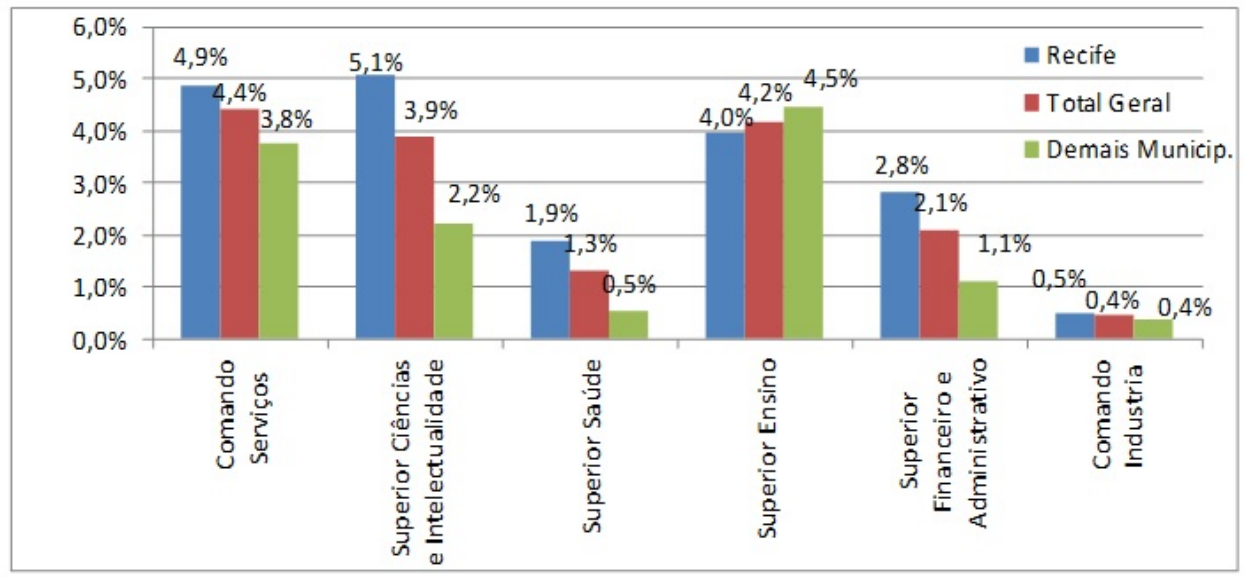

Fonte: Elaboração Própria, a partir de Censo 2010.

Obs: Volume total do município (para cada município) $=100 \%$.

A exceção é o segmento Superior Ensino. Esta categoria inclui os profissionais do ensino, portanto, além da rede básica de ensino e de nível médio, as universidades públicas e privadas e as escolas técnicas. Municípios com baixa complexidade de atividades econômicas contem uma estrutura ocupacional menos diversificada, onde o segmento de ensino acaba tendo peso relevante. Por isso, a participação deste segmento é maior no restante da RM $(4,5 \%)$ do que em Recife $(4,0 \%)$. 


\section{Perfil Ocupacional do Fluxo Pendular da Região Metropolitana de Recife}

A análise da pendularidade na RM de Recife revela que, do total de 1.512 .736 de ocupados, 21,3\% (322.643) não exercem sua ocupação no município em que reside, realizando deslocamento para outro município.

São as ocupações de nível médio as que mais se deslocam no território metropolitano, 141.490 pessoas (43,9\%), seguidas pelas de nível básico 103.709 (32,1\%), e por último, pelas de nível superior ou comando, 46.755 (14,5\%). O restante é classificado como outros, 25.569 (7,9\%), ou Militares, 5.120 (1,6\%).

O gráfico 5 representa o fluxo de ocupados o rendimento bruto por nível de especialização:

Gráfico 5: Participação do nível de especialização dos ocupados, segundo rendimento bruto e total de pessoas que se deslocam, na Região Metropolitana de Recife - 2010

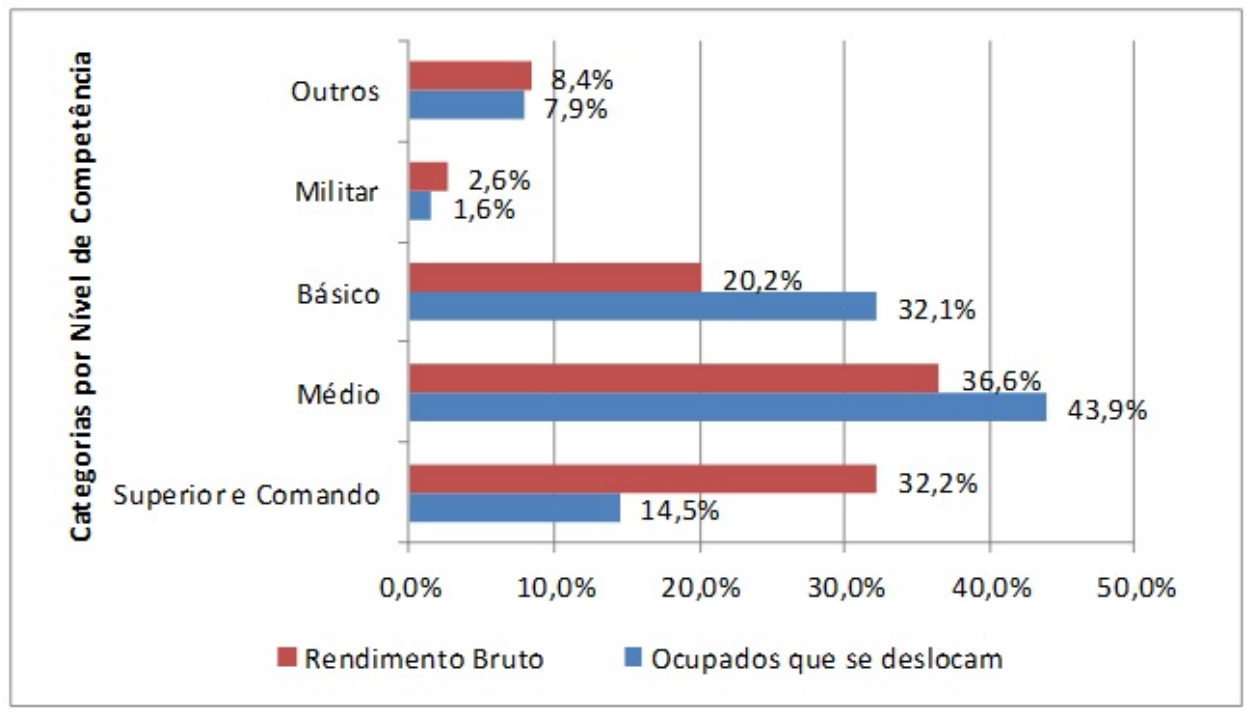

Fonte: Elaboração Própria, a partir de Censo 2010.

Pelo gráfico 5 acima, observa-se em relação ao somatório das remunerações das pessoas que se deslocam, que as ocupações básicas movimentam somente $20,2 \%$ do total do rendimento bruto. As ocupações médias, por sua vez, correspondem a $36,6 \%$ do total. Uma possível explicação para o fato dos ocupados de nível básico não representarem o maior volume de deslocamento, mesmo sendo a maioria ocupada na RM, é a maior facilidade que os municípios em geral têm de ofertar empregos de segmentos mais básicos (como o comércio e a prestação de serviços), retendo uma parte dessa mão de obra. Além disso, os próprios trabalhadores podem exercer alguma ocupação informal no seu município de residência, enquanto que os segmentos com qualificações de nível médio podem buscar melhores remunerações ou ocupações mais específicas, muitas vezes uma relação de trabalho formal com melhores condições.

Já os ocupados que atuam no nível superior e no comando que se deslocam possuem $32,2 \%$ do total do rendimento bruto, sendo assim, os terceiros colocados em fluxo na $\mathrm{RM}$, porém os segundos em somatório de rendimento. Suas remunerações são mais 
elevadas, e, os trabalhadores atuam em segmentos mais especializados, localizados em municípios específicos.

O número de ocupados que se destina a Recife para trabalhar, comparado aos outros municípios, é muito superior. Das 322.643 pessoas que se deslocam na RM, 72,0\% se dirigem a Recife. 0 principal par de origem-destino de ocupados é Jaboatão dos

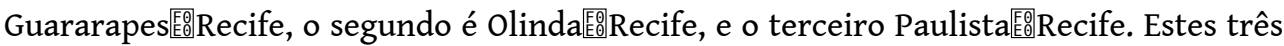
pares compõem a classe dos fluxos superiores a 40.000. Eles juntos correspondem a $54,2 \%$ do total.

Em segundo lugar a classe dos fluxos acima de 10.000 a 25.000 apresenta os pares

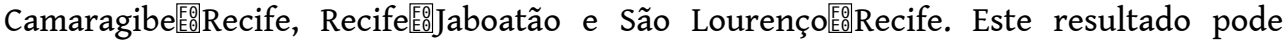
sugerir que o oeste da metrópole (Camaragibe e São Lourenço) é emissor de população, não figurando como receptores em nenhum dos fluxos mais volumosos (superiores a 2.000) ilustrados no mapa 1.

Em terceiro lugar a classe de 2.000 a 10.000 contendo como receptores: Recife, Jaboatão, Olinda, Paulista, Cabo de Santo Agostinho e Ipojuca. Portanto, da tabela dos principais fluxos conclui-se que os seis principais municípios receptores de fluxos pendulares estão localizados no centro e ao sul da metrópole.

O mapa 1, a seguir, contém os fluxos pendulares mais volumosos:

Mapa 1: Movimento pendular para trabalho, igual ou superior a 2000 pessoas, entre os municípios da Região Metropolitana de Recife - 2010

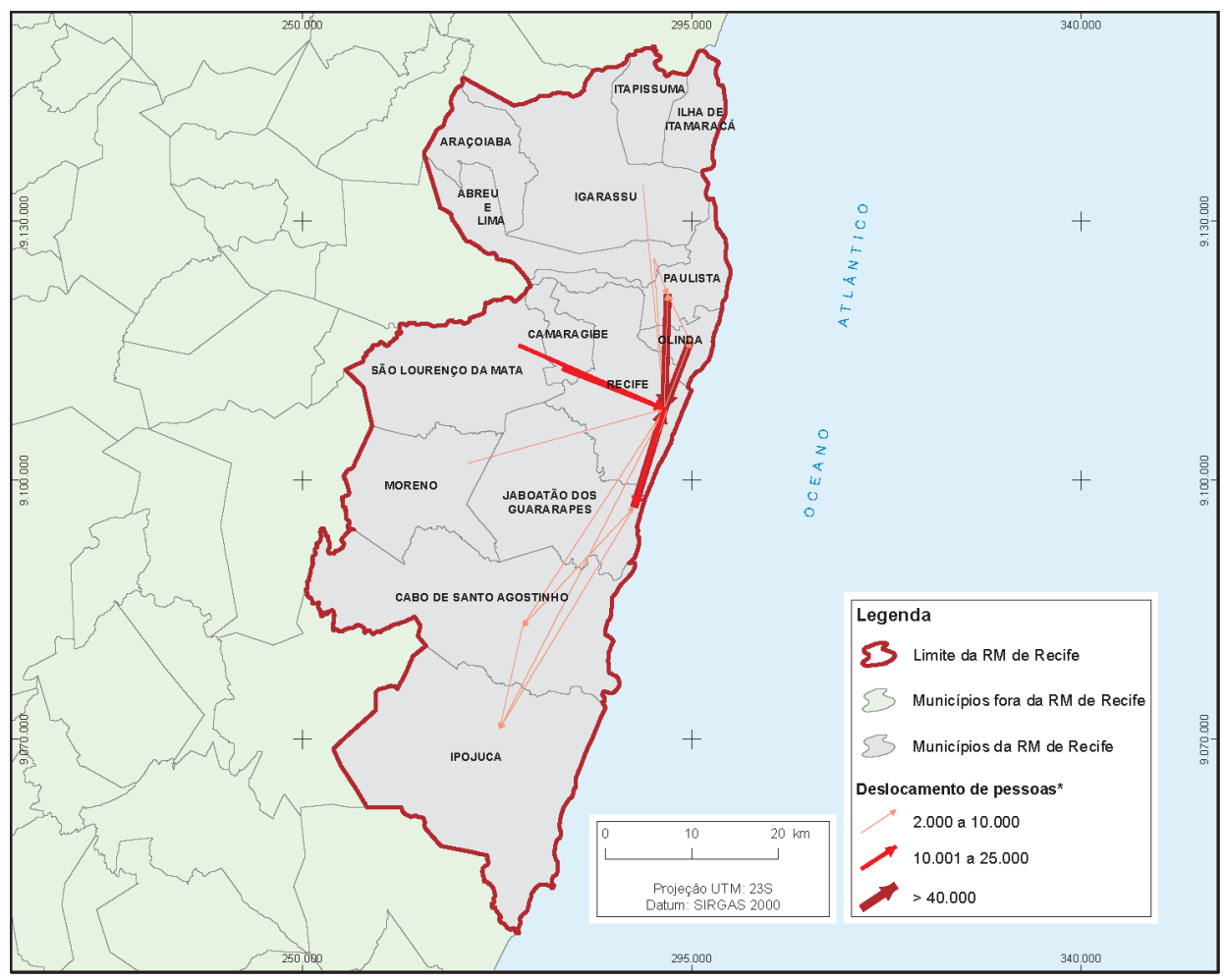

Fonte: Elaboração própria, a partir de IBGE, Censo 2010.

Nota: * Não existe nenhum registro com valor entre 25.001 e 40.000

Outro indicador, o Saldo do movimento de Ocupados (entrada de ocupados menos saída de ocupados) revela os municípios que estão absorvendo os ocupados. Contudo, o indicador não abarca a complexidade dos fatores que interferem ou explicam o 
deslocamento populacional, pois do ponto de vista quantitativo nem sempre os municípios com resultado positivo são aqueles que movimentam os maiores contingentes de ocupados.

Recife e Ipojuca são os únicos municípios que apresentam saldo positivo para todas as categorias ocupacionais. Portanto, eles recebem mais ocupados do que enviam para outros municípios da Região Metropolitana.

Em Ipojuca, juntamente com Cabo de Santo Agostinho, ao sul da Metrópole, está localizado o Complexo Industrial Portuário Suape. Trata-se de um empreendimento que engloba investimentos em petroquímica, refinaria, estaleiros, e pólo metal-mecânico: o Estaleiro Atlântico Sul, focado na produção de navios cargueiros - petroleiros, conteineiros, graneleiros e de cargas gerais, além de plataformas offshore, navios de perfuração e barcos de apoio à indústria petrolífera ${ }^{19}$; a Petroquímica Suape, um Complexo Industrial Químico-têxtil ${ }^{20}$; e a Refinaria Abreu e Lima, em construção ${ }^{21}$.

Enquanto Ipojuca apresenta um saldo total positivo de movimento de ocupados (10.879), Cabo tem um saldo negativo (-2.459). O Médio Indústria é o segmento que mais absorve o fluxo de ocupados com saldos positivos em Ipojuca (2.406 pessoas). Neste segmento, Ipojuca é o único município com saldo positivo, além de Recife.

O mapa 2 a seguir contém os pares de fluxos para o Médio Indústria:

Mapa 2: Movimento pendular para trabalho, na categoria Médio Indústria, entre os municípios da Região Metropolitana de Recife - 2010

Fonte: Elaboração própria, a partir de IBGE, Censo 2010.

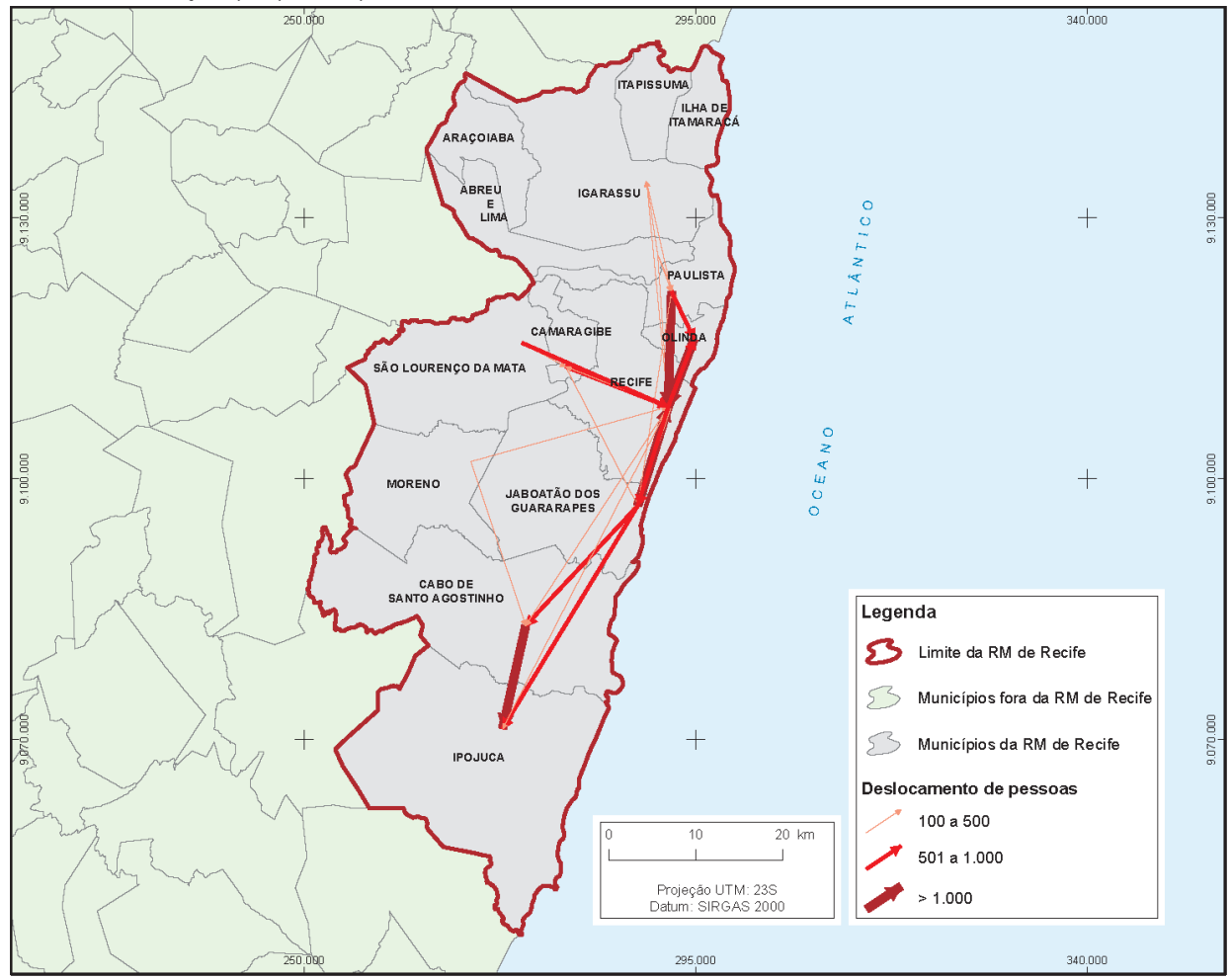

Além do par de Cabo de Santo Agostinho 鹿 Ipojuca, figuram entre os principais fluxos

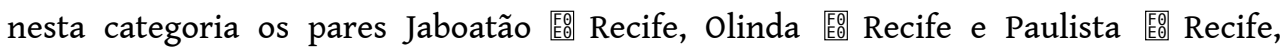
formando o grupo de pares com fluxos de mais de 1.000 pessoas. A segunda classe em 
volume de fluxos, de 501 a 1.000 pessoas, tem como receptores estes mesmos municípios citados acima.

Para a categoria Básico Indústria também Recife e Ipojuca são os únicos municípios a apresentarem saldo positivo, absorvendo os ocupados no segmento. Pelo mapa 3, podese observar a multiplicidade dos fluxos.

Mapa 3: Movimento pendular para trabalho, na categoria Básico Indústria, entre os municípios da Região Metropolitana de Recife - 2010

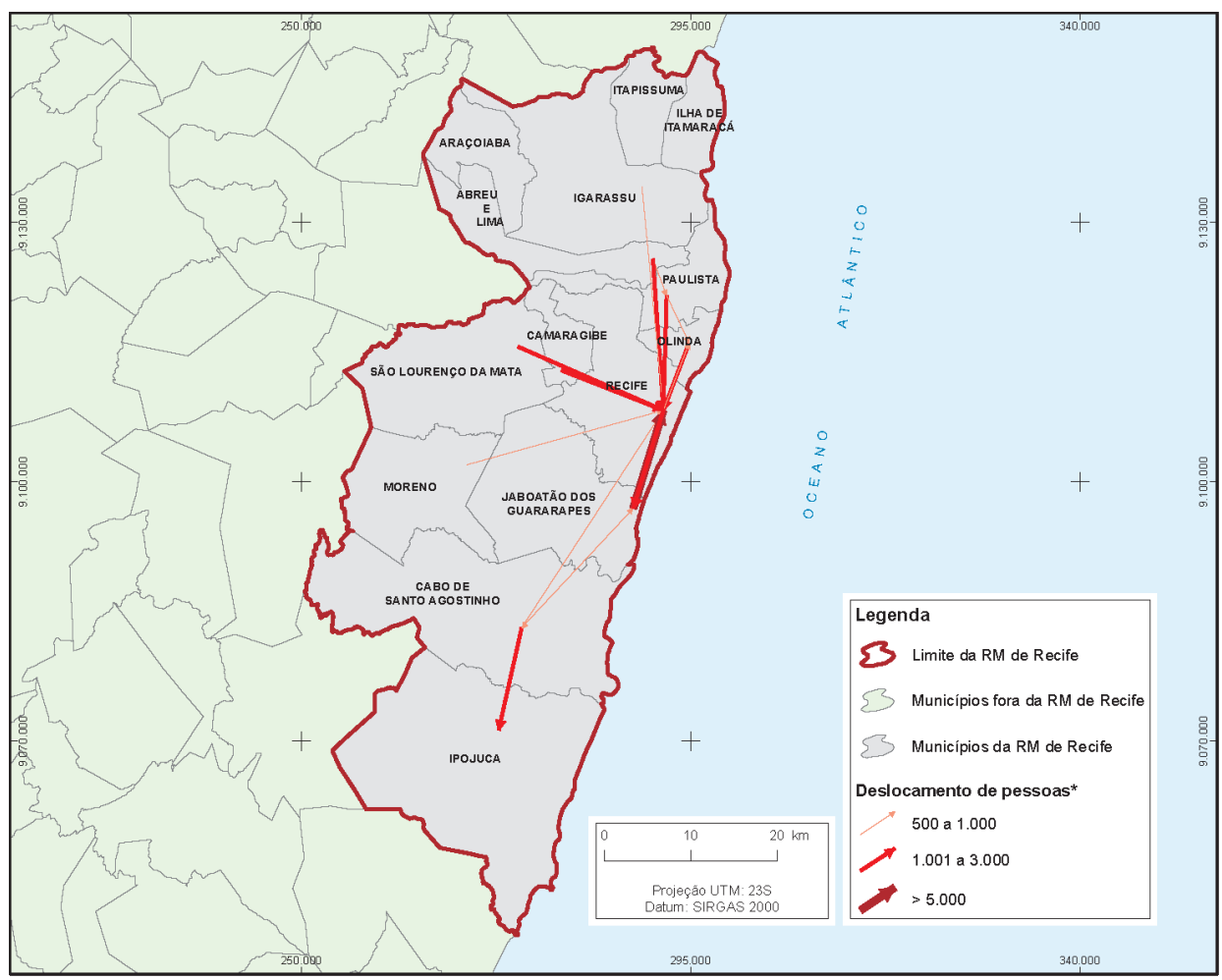

FONTE: ELABORAÇÃo PRÓPRIA, A PARTIR DE IBGE, CENSO 2010.

Nota: * Não existe nenhum registro com valor entre 3.001 e 4.999

Recife se destaca por receber o maior volume de fluxos, sendo o único na classe acima de 5.000, através do par Jaboatão 鹥 Recife. Ele também está na classe de 1.001 a 3.000, como principal receptor, juntamente com Jaboatão dos Guararapes e Ipojuca. Essa

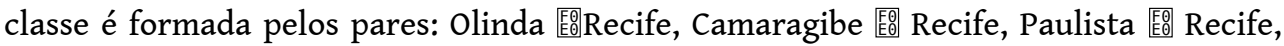

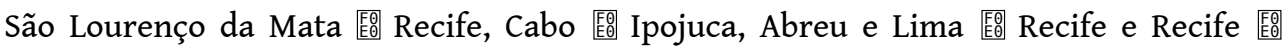
Jaboatão. Assim, constatam-se fluxos relevantes de diferentes partes da metrópole para o município-sede, ressaltando-se a emissão clara dos municípios do oeste (Camaragibe e São Lourenço da Mata) e a participação de Jaboatão e Ipojuca como receptores.

A terceira classe dos fluxos de 500 a 1.000 ocupados apresenta maior variedade de

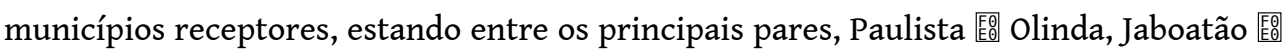
Cabo de Santo Agostinho e o inverso, Cabo 監 Jaboatão.

Por último, observam-se os fluxos dos ocupados que atuam nos segmentos comando e superior. Também para estes segmentos Recife e Ipojuca são os únicos que registram todos os saldos positivos. 
Pelo mapa 4 a seguir, constata-se que Recife é o principal receptor dos fluxos em volume, enquanto que Jaboatão dos Guararapes, Olinda e também Recife são os maiores emissores.

Mapa 4: Movimento pendular para trabalho, nas categorias Superior e Comando, entre os municípios da Região Metropolitana de Recife - 2010

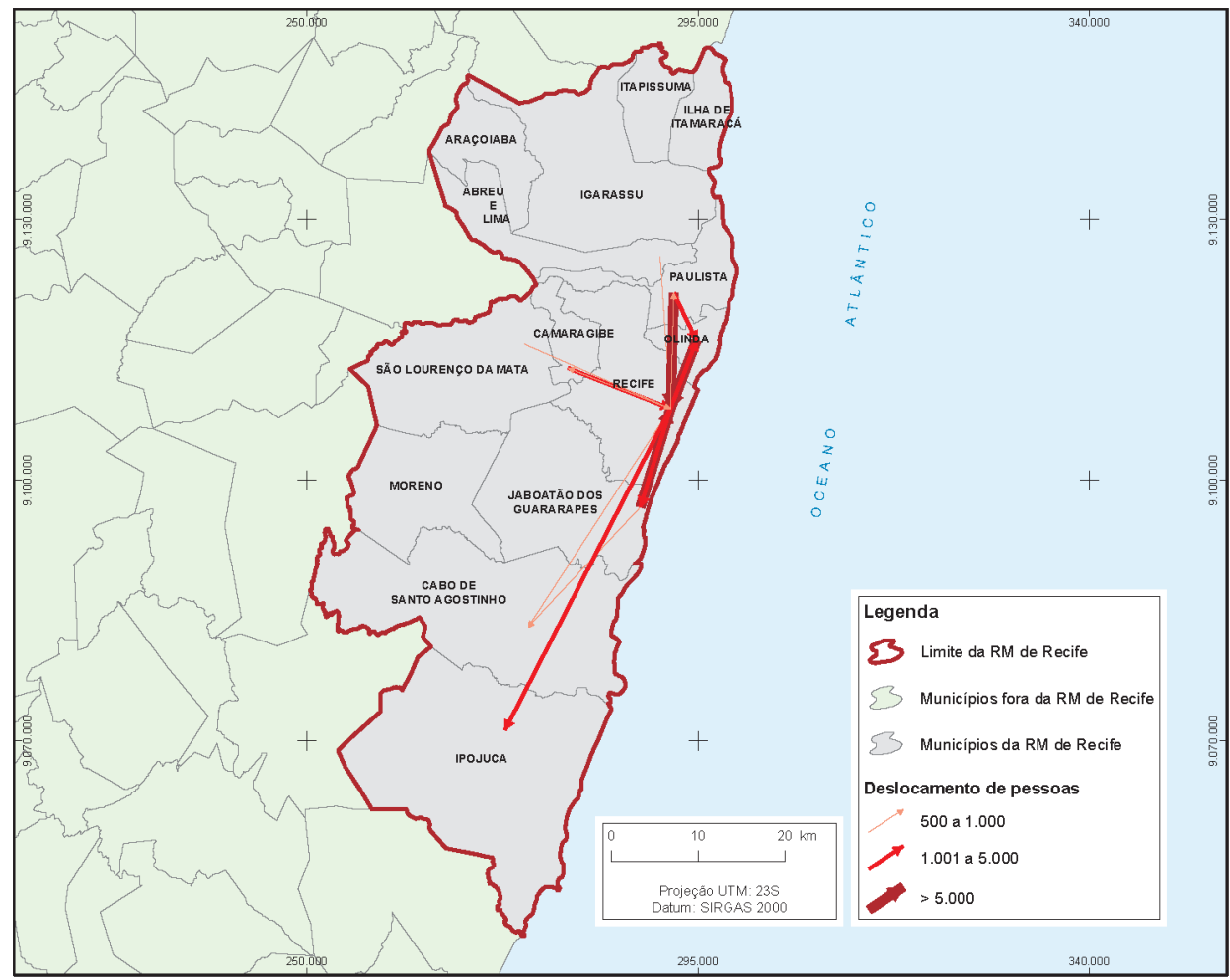

Fonte: Elaboração própria, a partir de IBGE, Censo 2010.

Nos fluxos superiores a 5.000 pessoas, somente Recife recebe ocupados, sendo Olinda, Jaboatão e Paulista os emissores. Nos fluxos de 1.001 a 5.000, Jaboatão e Olinda que recebem os maiores contingentes de pessoas para ocupar-se em algum segmento superior ou como dirigente, mas também estão nessa classe Ipojuca e Recife. São cinco

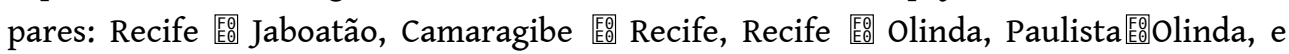
Recife 庮 Ipojuca. E, por último, para a classe dos fluxos de 500 a 1.000 além de Recife novamente, Cabo de Santo Agostinho e Camaragibe são os principais destino dos fluxos,

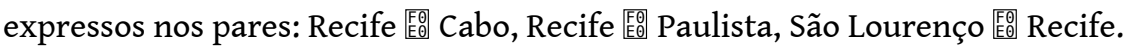

A maior parte dos fluxos mais volumosos envolvem os municípios da região central (Recife, Olinda, Jaboatão e Paulista). As exceções são o par Camaragibe 䦪 Recife na faixa de 1.001 a 5.000 e o par Recife 麋 Ipojuca na faixa de 501 a 1.000.

\section{Considerações Finais}

Estudar o perfil ocupacional da população que realiza movimento pendular na Região Metropolitana de Recife, a partir dos dados do Censo 2010, exigiu esforços no sentido da construção de metodologia empírica para organização e análise de dados.

$\mathrm{Na}$ RM Recife, pelos dados selecionados, segundo a metodologia apresentada, 21,3\% dos ocupados não exercem a ocupação no município em que residem. Os mais volumosos 
fluxos ocorrem na direção de, e, entre, Recife e os municípios vizinhos de Jaboatão dos Guararapes, Olinda e Paulista. Estes possuem contiguidades urbanas, e podem ser considerados conurbados, ou, um núcleo estendido. Somente Recife recebe $72,0 \%$ do total do fluxo pendular por motivo de trabalho.

Tal resultado pode estar associado ao padrão centro-periferia, característico do fenômeno metropolitano brasileiro, em que o núcleo central da região metropolitana concentra serviços, empregos, infraestrutura, em torno dos quais gravita a população metropolitana como um todo. A periferia por sua vez, não excluindo outros determinantes espaciais, em linhas gerais é formada a partir da expansão do centro e dos mecanismos de segregação socioespacial.

Registra-se como segundo eixo de atração de movimento pendular o litoral sul da RM, em especial os municípios de Cabo de Santo Agostinho e Ipojuca. Estes dividem o território produzido pelo Complexo de Suape, com intensa atividade portuária e industrial. Apesar de não ter sido instalado propriamente no coração do centro metropolitano, Suape está a 40 quilômetros de Recife e pode, assim, desfrutar das vantagens da aglomeração de Recife, principalmente da mão de obra qualificada.

Com relação aos municípios do norte da RM (Abreu e Lima, Igarassu, Itapissuma, Itamaracá, Araçoiaba) chama atenção a atividade industrial em Goiana, município externo a região metropolitana, mas que vem exercendo atração para novas industrias nos limites da RM. Os municípios localizados no Oeste da RM (São Lourenço da Mata, Camaragibe e Moreno) aparecem como emissores de população para o núcleo.

As ocupações do segmento terciário são maioria, principalmente nos Serviços, confirmando o caráter terciário da metrópole. Compõem o grande grupo das ocupações terciárias aquelas dos ramos de Ensino, Saúde, Ciências e Intelectualidade, Financeiro e Administrativo, Administração Pública e Comércio. Portanto, este mesmo grupo engloba ocupações com graus de especialização diversos. Ressaltam-se os ocupados no nível superior nos Serviços e nas Ciências e Intelectualidades em Recife, e a categoria Superior Ensino ter importância relativa maior nos demais municípios da RM.

Destaca-se a relativa desconcentração espacial da indústria. O fluxo de ocupados na categoria Médio Indústria mais volumoso ocorre na direção de Recife e de Ipojuca, únicos municípios a registrar saldo de movimento de ocupados positivo. $\mathrm{O}$ fluxo de ocupados na categoria Básico Indústria mais volumoso ocorre preferencialmente na direção de Recife. Também há fluxos relevantes na direção de Ipojuca, Cabo de Santo Agostinho, Jaboatão e Olinda. Outros municípios da RM recebem ocupados, porém são pares em classes inferiores a 500 pessoas - Igarassu, Abreu e Lima e Paulista. Portanto, verifica-se que a relativa desconcentração das ocupações industriais pela região metropolitana ainda é acompanhada por um grande fluxo pendular em direção a capital Recife.

Por nível de especialização, a maior parcela do deslocamento pendular é realizada por ocupados de nível médio - $43,9 \%$ - que movimentam $36,6 \%$ do total do rendimento bruto dos ocupados pendulares. Os ocupados de nível básico por sua vez totalizam $32,1 \%$ do fluxo e $20,2 \%$ do rendimento. O contraste fica com os ocupados do nível superior que totalizam somente $14,5 \%$ do fluxo, responsáveis por $32,2 \%$ do rendimento.

Estas informações indicam em linhas gerais os eixos de deslocamento dos ocupados na Região Metropolitana de Recife. A mobilidade pendular da população, em grande medida, reflete os processos de segregação socioespacial produzidos no modelo de metropolização brasileiro. Enfatiza-se a necessidade de aperfeiçoamento metodológico, 
aliado a estudos sobre o processo de urbanização, as transformações urbanas e as transformações econômicas como chaves fundamentais para futuras explorações.

Quadro I: Novas Categorias Ocupacionais

\begin{tabular}{|c|c|}
\hline Novas Categorias Ocupacionais & Ocupações e Códigos (BME/IBGE) \\
\hline \multirow{7}{*}{ Militar } & 11 - Oficiais das forças armadas \\
\hline & 21 - Graduados e praças das forças armadas \\
\hline & 29 - Militar das Forças Armadas N.E. \\
\hline & 41 - Policiais militares \\
\hline & 51 - Bombeiros militares \\
\hline & 59 - Bombeiros e Policiais Militares N.E. \\
\hline & $\begin{array}{l}99 \text { - Membros das Forças Armadas, Policiais e Bombeiros } \\
\text { Militares N.E. }\end{array}$ \\
\hline \multirow{2}{*}{$\begin{array}{l}\text { Comando Executivo Legislativo } \\
\text { Judiciário }\end{array}$} & 111 - Membros superiores do poder executivo e legislativo \\
\hline & 112 - Diretores gerais e gerentes gerais \\
\hline Comando Agropecuária & $\begin{array}{l}131 \text { - Dirigentes de produção agropecuária, silvicultura, } \\
\text { aquicultura e pesca }\end{array}$ \\
\hline Comando Indústria & $\begin{array}{l}132 \text { - Dirigentes de indústria de transformação, mineração, } \\
\text { construção e distribuição }\end{array}$ \\
\hline Comando & 121 - Dirigentes de administração e de serviços \\
\hline \multirow[t]{6}{*}{ Serviços } & 122 - Dirigentes de vendas, comercialização e desenvolvimento \\
\hline & $\begin{array}{l}133 \text { - Dirigentes de serviços de tecnologia da informação e } \\
\text { comunicações }\end{array}$ \\
\hline & 134 - Dirigentes e gerentes de serviços profissionais \\
\hline & 141 - Gerentes de hotéis e restaurantes \\
\hline & 142 - Gerentes de comércios atacadistas e varejistas \\
\hline & 143 - Outros gerentes de serviços \\
\hline \multirow{3}{*}{$\begin{array}{l}\text { Superior Ciências } \quad \mathrm{e} \\
\text { Intelectualidade }\end{array}$} & 211 - Físicos, químicos e afins \\
\hline & 212 - Matemáticos, atuários e estatísticos \\
\hline & 213 - Profissionais em ciências biológicas \\
\hline
\end{tabular}




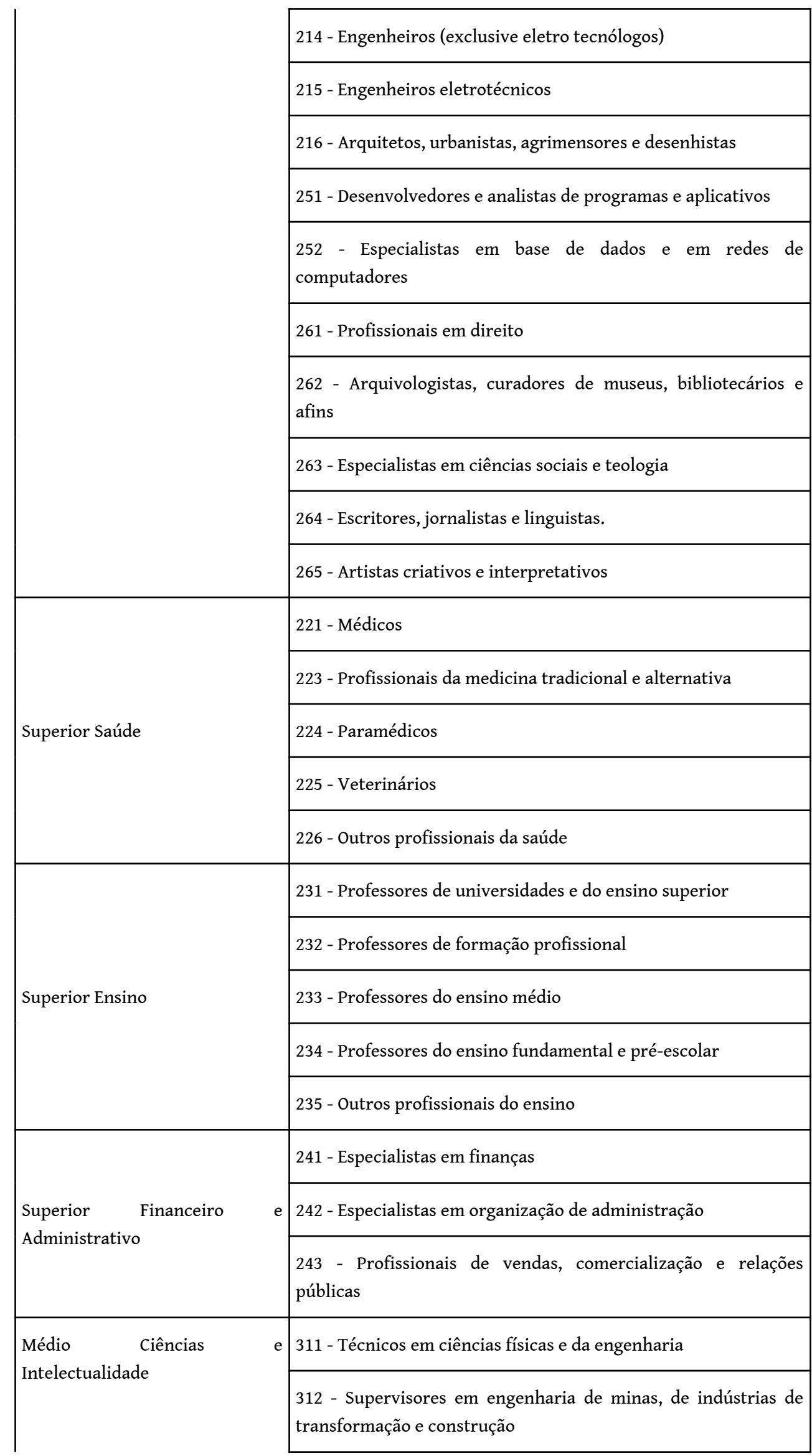




\begin{tabular}{|c|c|}
\hline & 313 - Técnicos em controle de processos \\
\hline & $\begin{array}{l}314 \text { - Técnicos e profissionais de nível médio em ciências } \\
\text { biológicas e afins }\end{array}$ \\
\hline & $\begin{array}{l}315 \text { - Técnicos e controladores da navegação marítima e } \\
\text { aeronáutica }\end{array}$ \\
\hline & $\begin{array}{l}341 \text { - Profissionais de nível médio de serviços jurídicos, sociais e } \\
\text { religiosos. }\end{array}$ \\
\hline & 342 - Trabalhadores do esporte e condicionamento físico \\
\hline & $\begin{array}{l}343 \text { - Profissionais de nível médio em atividades culturais, } \\
\text { artísticas e culinárias. }\end{array}$ \\
\hline & $\begin{array}{l}351 \text { - Técnicos em operações de tecnologia da informação e das } \\
\text { comunicações e }\end{array}$ \\
\hline & assistência ao usuário \\
\hline & 352 - Técnicos em telecomunicações e radiodifusão \\
\hline Médio Saúde & 222 - Profissionais de enfermagem e partos \\
\hline & 331 - Profissionais de nível médio em finanças e matemática \\
\hline & 332 - Agentes e corretores comerciais \\
\hline $\begin{array}{l}\text { Médio Financeiro } \\
\text { Administrativo }\end{array}$ & 333 - Agentes de serviços comerciais \\
\hline & 334 - Secretários administrativos e especializados \\
\hline & 431 - Auxiliares contábeis e financeiros \\
\hline $\begin{array}{l}\text { Médio no Executivo, legislativo e } \\
\text { Judiciário }\end{array}$ & $\begin{array}{l}335 \text { - Agentes da Administração Pública para aplicação da lei e } \\
\text { afins }\end{array}$ \\
\hline Médio Serviços & 411 - Escriturários gerais \\
\hline & 412 - Secretários (geral) \\
\hline & 413 - Operadores de máquinas de escritório \\
\hline & 421 - Caixas de banco, cobradores, pagadores e afins \\
\hline & 422 - Trabalhadores de serviços de informação ao cliente \\
\hline & $\begin{array}{l}432 \text { - Trabalhadores encarregados de registros de materiais e de } \\
\text { transportes }\end{array}$ \\
\hline & 511 - Trabalhadores do serviço direto aos passageiros \\
\hline
\end{tabular}




\begin{tabular}{|c|c|}
\hline & 515 - Supervisores de manutenção e limpeza de edifícios \\
\hline & 541 - Trabalhadores dos serviços de proteção e segurança \\
\hline \multirow{4}{*}{ Médio Agropecuária } & $\begin{array}{l}611 \text { - Agricultores e trabalhadores qualificados em atividades da } \\
\text { agricultura }\end{array}$ \\
\hline & 612 - Criadores e trabalhadores qualificados da pecuária \\
\hline & $\begin{array}{l}613 \text { - Produtores e trabalhadores qualificados de exploração } \\
\text { agropecuária mista }\end{array}$ \\
\hline & 621 - Trabalhadores florestais qualificados e afins \\
\hline \multirow{11}{*}{ Médio Indústria } & 712 - Trabalhadores qualificados da construção (acabamento) \\
\hline & $\begin{array}{l}721 \text { - Moldadores, soldadores, chapistas, caldeireiros, } \\
\text { montadores de estr. metálicas e afins }\end{array}$ \\
\hline & 741 - Instaladores e reparadores de equipamentos elétricos \\
\hline & $\begin{array}{l}742 \text { - Instaladores e reparadores de equipamentos eletrônicos e } \\
\text { Telecomunicações }\end{array}$ \\
\hline & $\begin{array}{l}751 \text { - Trabalhadores qualificados do processamento de alimentos } \\
\text { e afins }\end{array}$ \\
\hline & $\begin{array}{l}752 \text { - Trabalhadores qualificados do tratamento da madeira, } \\
\text { marceneiros, etc }\end{array}$ \\
\hline & $\begin{array}{l}753 \text { - Trabalhadores qualificados e operários da confecção de } \\
\text { roupas, calçados e acessórios }\end{array}$ \\
\hline & $\begin{array}{l}754 \text { - Outros trabalhadores qualificados e operários da indústria } \\
\text { e do artesanato }\end{array}$ \\
\hline & $\begin{array}{l}811 \text { - Operadores de instalações mineradoras e de extração e } \\
\text { processamento de minerais }\end{array}$ \\
\hline & $\begin{array}{l}813 \text { - Operadores de instalações e máq. e produtos químicos e } \\
\text { fotográficos }\end{array}$ \\
\hline & 821 - Montadores \\
\hline \multirow{3}{*}{ Médio Comércio } & 512 - Cozinheiros \\
\hline & 522 - Comerciantes e vendedores de lojas \\
\hline & 523 - Caixas e expedidores de bilhetes \\
\hline & 622 - Pescadores e caçadores \\
\hline
\end{tabular}

Básico Agropecuária 


\begin{tabular}{|c|c|}
\hline & $\begin{array}{l}921 \text { - Trabalhadores elementares da agropecuária, da pesca e } \\
\text { florestais }\end{array}$ \\
\hline & 441 - Outros trabalhadores de apoio administrativo \\
\hline & 516 - Outros trabalhadores de serviços pessoais \\
\hline & 831 - Maquinistas de locomotivas e afins \\
\hline & 832 - Condutores de automóveis, caminhonetes e motocicletas \\
\hline & 833 - Condutores de caminhões pesados e ônibus \\
\hline & 834 - Operadores de equipamentos móveis pesados \\
\hline & 835 - Marinheiros de coberta e afins \\
\hline & $\begin{array}{l}911 \text { - Trabalhadores domésticos e outros trabalhadores de } \\
\text { limpeza no interior de edifícios }\end{array}$ \\
\hline & $\begin{array}{l}912 \text { - Lavadores de veículos, janelas, roupas e outras limpezas } \\
\text { manuais }\end{array}$ \\
\hline & $\begin{array}{l}933 \text { - Trabalhadores elementares do transporte e } \\
\text { armazenamento }\end{array}$ \\
\hline & 941 - Ajudantes de preparação de alimentos \\
\hline & 951 - Trabalhadores ambulantes dos serviços e afins \\
\hline & $\begin{array}{l}952 \text { - Vendedores ambulantes (exclusive de serviços de } \\
\text { alimentação) }\end{array}$ \\
\hline Básicos Serviços & 961 - Coleta de lixo \\
\hline Básico Indústria & 711 - Trabalhadores da construção civil em obras estruturais \\
\hline & 713 - Pintores, limpadores de fachadas e afins \\
\hline & 722 - Ferreiros, ferramenteiros e afins \\
\hline & 723 - Mecânicos e reparadores de máquinas \\
\hline & $\begin{array}{l}812 \text { - Operadores de instalações de processamento e } \\
\text { recobridoras de metais }\end{array}$ \\
\hline & $\begin{array}{l}814 \text { - Operadores de máquinas para fabricar produtos de } \\
\text { borracha, papel e material plástico }\end{array}$ \\
\hline & $\begin{array}{l}815 \text { - Operadores de máquinas para fabricar produtos de têxteis } \\
\text { e artigos de couro e pele }\end{array}$ \\
\hline
\end{tabular}




\begin{tabular}{|c|c|}
\hline & $\begin{array}{l}816 \text { - Operadores de máquinas para elaborar alimentos e } \\
\text { produtos afins }\end{array}$ \\
\hline & $\begin{array}{l}817 \text { - Operadores de instalações para a preparação de papel e de } \\
\text { processamento de madeira }\end{array}$ \\
\hline & 818 - Outros operadores de instalações fixas e máquinas \\
\hline & 931 - Trabalhadores elementares da mineração e da construção \\
\hline & 932 - Trabalhadores elementares da indústria de transformação \\
\hline & 513 - Garçons e atendentes de bar \\
\hline & 514 - Cabeleireiros, especialistas em tratamento de beleza e afins \\
\hline & 521 - Vendedores de rua e postos de mercado \\
\hline & 524 - Outros vendedores \\
\hline Básico Ensino & 531 - Cuidadores de crianças e ajudantes de professores \\
\hline & 731 - Artesãos \\
\hline Outros & 962 - Outras ocupações elementares \\
\hline & 0 - Ocupações mal definidas \\
\hline
\end{tabular}

\section{BIBLIOGRAFIA}

AGÊNCIA NACIONAL DE TRANSPORTES AQUAVIÁRIOS. Porto de Suape. Disponível em: goo.gl/ zFsKdg. Acesso em 12 de abril de 2015.

BANCO MULTIDIMENSIONAL DE ESTATÍSTICAS. Censo 2010. Amostras. Disponível em: < http:// goo.gl/01dE6Y >. Acesso em: março a setembro de 2014.

BITOUN, J. et al. Região Metropolitana de Recife no Contexto de Pernambuco no Censo 2010.Recife: Observatório das Metrópoles. Disponível em: < http://goo.gl/i0zFzg >. Acesso em: 27 de julho de 2014.

CARLOS, A.F.A. Da Organização à Produção do Espaço no Pensamento Geográfico. In: CARLOS, A.F.A; SOUZA, M.L.; SPOSITO, M.E.B (Org). A Produção do Espaço Urbano: agentes e processos, escalas e desafios. São Paulo: Editora Contexto, 2011. p.53-73.

CASTELLS, M. A Sociedade em Rede (Prefácio à edição de 2010). In: A Era da Informação: economia, sociedade e cultura. Vol. I. Rio de Janeiro: Paz e Terra, 2011. 
ESTALEIRO ATLÂNTICO SUL. Disponível em: < http://goo.gl/nCEJM > . Acesso em: 17 de agosto de 2016.

GOVERNO DO ESTADO DE PERNAMBUCO. Invest in Pernambuco. Disponível em: < http://goo.gl/ IN1QQ6>. Acesso em: 16 de outubro de2014.

INSTITUTO BRASILEIRO DE GEOGRAFIA E ESTATÍSTICA (IBGE). IBGE/CIDADES - Banco de dados Pernambuco. Disponível em: < http://goo.gl/JIqTCE >. Acesso em: 27 de agosto de2014.

INSTITUTO BRASILEIRO DE GEOGRAFIA E ESTATÍSTICA (IBGE). Regiões de Influência das Cidades 2007. Rio de Janeiro: IBGE: 2008.

INSTITUTO BRASILEIRO DE GEOGRAFIA E ESTATÍSTICA (IBGE). Metodologia do Censo Demográfico 2010. Série Relatórios Metodológicos, v.41, 2013, p. 52 - 56 e 338-340. Disponível em: goo.gl/IXGBWA.

INSTITUTO DE PESQUISA ECONÔMICA APLICADA; INSTITUTO BRASILEIRO DE GEOGRAFIA E ESTATÍSTICA; UNIVERSIDADE ESTADUAL DE CAMPINAS. Série Caracterização e Tendências da Rede Urbana do Brasil. Motta, Diana Meirelles da. Org. Brasília (DF) 2002.

JARDIM, A. P de. Reflexões sobre mobilidade pendular. In: OLIVEIRA, L. A. P.; OLIVEIRA, A. T. R. Reflexões sobre os deslocamentos populacionais no Brasil. Estudos e Análises. Rio de Janeiro: IBGE, 2011. Disponível em: < http://goo.gl/UAOeL >. Acesso em: outubro de 2014.

MARINHO, G.; LEITÃO, L.; LACERDA, N. Transformações Urbanísticas na Região Metropolitana de Recife: um estudo prospectivo. Cadernos Metrópole. São Paulo, n.17, p.193-217, 1ํsem/2007. MINISTÉRIO DO TRABALHO E EMPREGO. Classificação Brasileira de Ocupações. Disponível em: < http://goo.gl/VUz3j >. Acesso em: 17 de julho de2014.

MOURA, R. BRANCO, M.L.G.C; FIRKOWSKI, O.L.C.F. (out/dez. 2005), “Movimento Pendular e Perspectivas de Pesquisas em Aglomerados Urbanos”. São Paulo em Perspectiva, v.19, n.4, pp. 121-133.

OBSERVATÓRIO DAS METRÓPOLES. Análise das Regiões Metropolitanas do Brasil: Identificação dos Espaços Metropolitanos e Construção de Tipologias. Relatório da atividade 1: Rio de Janeiro: FASE/IPPUR/IPARDES. Dez.2004. Disponível em: < http://goo.gl/mRgWbe >. Acesso em: agosto/setembro/outubro de 2014.117f.

OBSERVATÓRIO DAS METRÓPOLES. Arranjos Institucionais para a Gestão Metropolitana. Projeto Observatório das Metrópoles: território, coesão social e governança democrática. Relatório de Pesquisa. Out. 2009. Disponível em: < http://goo.gl/jqF7Kk >. Acesso em: setembro de 2014. 118f.

OBSERVATÓRIO DAS METRÓPOLES; UNIVERSIDADE FEDERAL DE PERNAMBUCO; FEDERAÇÃO DE ÓRGÃOS PARA ASSISTÊNCIA SOCIAL E EDUCACIONAL; OBSERVATÓRIO PERNAMBUCO DE POLÍTICAS PÚBLICAS E PRÁTICAS SOCIO-AMBIENTAIS. Como Anda a Região Metropolitana de Recife? Set.2006. Disponível em: < http://goo.gl/Mmgsj >. Acesso em: outubro de 2014. $128 f$.

PETROBRAS. Refinaria Abreu e Lima. Disponível em: < http://goo.gl/5WE0Fz>. Acesso em 17 de agosto de 2016.

PETROQUÍMICA SUAPE. Disponível em: <http://goo.gl/YOxshw>>. Acesso em: 17 de agosto de 2016.

PIQUET, R. O Emprego Industrial Metropolitano e a Nova Divisão Espacial do Trabalho no Brasil. Revista Brasileira de Estudos Urbanos e Regionais (ANPUR). Recife, nº 3, p. 97-110, nov. 2000. 
PORTO DIGITAL. Institucional. Disponível em: < http://goo.gl/fPSJE >. Acesso em: 09 de outubro de 2014.

SANTOS, M. A Urbanização Brasileira. São Paulo: Editora Hucitec, 1993.

SASSEN, S. A Cidade Global. 1991. Texto apresentado na Conferência sobre Cidades e Espaço, Belo Horizonte, 1991.

SOUZA, N. de J. Teoria dos Polos, Regiões Inteligentes e Sistemas Regionais de Inovação. Análise, Porto Alegre, v. 16, n. 1, p. 87-112, jan./jul. 2005.

STORPER, M; VENABLES, A. O Burburinho. A força econômica das cidades. In: DINIZ, C. C.; LEMOS, M.B. Economia e Território. Belo Horizonte: Editora UFMG, 2005 pp 21-56.

\section{ANEXOS}

Anexo

Fonte: Elaboração Própria.

\section{NOTAS}

1. OBSERVATÓRIO DAS METRÓPOLES, 2009, p.12.

2. Ibidem, p.14

3. SANTOS, 1993

4. OBSERVATÓRIO DAS METRÓPOLES, 2004, p. vii

5. CASTELLS, 2011, p. XVIII

6. SANTOS, 1993, p. 102 - 114

7. OBSERVATÓRIO DAS METRÓPOLES, 2006, p.20

8. MOURA, BRANCO, FIRKOWSKI, 2005

9. Ibidem, p. 65.

10. PIQUET, 1997, p. 100

11. CASTELLS, 2011, p.viii.

12. SASSEN, 1993, p. 195 - 201

13. IPEA/IBGE/UNICAMP. Caracterização e Tendências da Rede Urbana Brasileira, 2002, 114-119.

14. PORTO DIGITAL, 2014, s/p

15. IPEA/IBGE/UNICAMP. Op Cit, p.119.

16. CENSO DEMOGRÁFICO 2010, pag. 340

17. Ao se extrair do BME os dados em níveis mais desagregados (com uma conta de usuário de perfil "externo"), muitas vezes os mesmos são omitidos devido a questões de sigilo. Desta forma, os valores expressos nas análises subsequentes são fruto desta característica, assim como, os totais apresentados são resultado da soma destes valores segundo as classes adotadas. Isso significa que caso se extraia os dados em níveis mais agregados, valores diferentes podem vir a ser encontrados, porém, como este estudo foca nos grandes processos vigentes na RM de Recife, entende-se que os resultados não são afetados. Mais detalhes sobre o assunto consultar "IBGE, Metodologia do Censo Demográfico 2010" (p. 52 - 56).

18. IBGE CIDADES, 2011

19. Disponível em:< http://www.estaleiroatlanticosul.com.br/>. Acesso em 17/08/2016.

20. Disponível em: <http://www.pqspe.com.br/a-empresa/apresentacao>. Acesso em 17/08/2016). 
21. Disponível em: <http://www.petrobras.com.br/pt/nossas-atividades/principais operacoes/ refinarias/refinaria-abreu-e-lima.htm>. Acesso em 17/08/2016).

\section{RESUMOS}

Este artigo expõe o esforço metodológico de construção de categorias ocupacionais para qualificar o movimento pendular na região metropolitana de Recife utilizando dados do Censo Demográfico de 2010 organizados segundo critérios de atividades socioeconômicas e nível de especialização. Os principais resultados apontam para uma concentração do fluxo pendular no centro da região metropolitana e, secundariamente, fluxos em direção ao sul da metrópole, onde importantes investimentos econômicos estão ocorrendo estimulados pela formação do Complexo de Suape. Em relação ao perfil dos ocupados, confirma-se o caráter terciário da metrópole, revelando-se adicionalmente resultados diferenciados no setor Industrial.

A partir des données du Census Démographique de 2010 organisés selon les activités économiques et le niveau de spécialisation, on a fait un effort méthodologique de construction de catégories occupationelles afin de qualifier la mobilité pendulaire dans la Région Métropolitaine de Recife (PE). Les résultats principaux indiquent une concentration du flux pendulaire au centre de la région métropolitaine et, en termes secondaires, des flux vers le sud de la métropole (là où des importantes investissements sont stimulés par le Complex de Suape). En ce qui concerne au profil des occupés, on confirme la nature terciaire de la métropole, mais aussi des différents résultats dans le secteur industriel.

This article exposes the methodological efforts to create occupation categories in order to classify commuting within the Recife Metropolitan Region, based on Demographic Census 2010 data. The criteria adopted to organize this data were the socio-economic activities and specialization. The main outcomes indicates a concentration of commuting flows at the core of the metropolitan region, and, in a minor degree, there also some southward flows, where important investments have been taking place as a consequence of the construction of the Suape complex. Regarding the occupied profiles, the tertiary function of the metropolis has been confirmed, with some additional results associated with industrial sector.

Este artículo presenta un esfuerzo metodológico para realizar una construcción de categorías ocupacionales capaces de cualificar el movimiento pendular de los ocupados en la región metropolitana de Recife. Para ello, son utilizados los datos del Censo de 2010, que están organizados segundo criterios de las actividades socioeconómicas y del nivel de especialización. Los principales flujos ocupacionales estan en el centro de la región metropolitana, en seguida, los flujos hacia el sur de la metropole, donde importantes investimentos económicos han ocurrido, sobre todo, estimulados por la construcción del Complexo de Suape. Con relación al perfil ocupacional, está confirmado la función terciaria de la metropole, agregando resultados diferenciados en el sector industrial. 
ÍNDICE

Keywords: Metropolitan Region, commuting, occupation, Recife, work

Palabras claves: región metropolitana, movimiento pendular, ocupación, Recife, trabajo.

Palavras-chave: Região Metropolitana, movimento pendular, ocupação, Recife, trabalho

Mots-clés: Région Métropolitaine, mobilité pendulaire, occupation, Recife, travail.

\section{AUTORES}

\section{CLARICE ANTOUN MARTINHO}

Economista (UFRJ), Mestre em Planejamento Urbano e Regional (IPPUR/UFRJ), Especialista em Análise Ambiental e Gestão do Território (ENCE/IBGE). Consultora credenciada no Sebrae-RJ; Tutora e Mediadora no PQGA/IBAM. clariceantoun@gmail.com

\section{MAURICIO GONÇALVES E SILVA}

Geógrafo (UFRJ), Mestre em Engenharia da Computação - Área de Concentração Geomática (UERJ). Tecnologista da Coordenação de Geografia da Diretoria de Geociências do IBGE. mauricio.g.silva@ibge.gov.br

\section{CESAR AJARA}

Geógrafo, Doutor em Geografia (UFRJ). Docente e pesquisador no Programa de Pós-Graduação em População, Território e Estatísticas Públicas, na Coordenação de Pós-Graduação da Escola Nacional de Ciências Estatísticas do IBGE. cesarajara@outlook.com 